\title{
Development of Student Worksheets (LKPD) Based on Problem Based Learning to Improve Learning Outcomes in Business Economics Subjects
}

\author{
Monika Karolina Sianturi, Arwansyah, Muhammad Yusuf \\ Universitas Negeri Medan, Indonesia \\ monika.sianturi26@gmail.com
}

\begin{tabular}{ll}
\hline Article History & Received : July 9th 2021 \\
& Revision : August $17^{\text {th }} 2021$ \\
& Publication : Sept 30th 2021 \\
\hline
\end{tabular}

\begin{abstract}
The curriculum in Indonesia is currently curriculum 2013, especially on the basic framework and structure of the vocational curriculum that states that the 2013 curriculum was developed with the improvement of mindset, among others: educationthat focuses on teachers so focused on students, as well as passive learning so active learning. Therefore, as a teacher can develop the learning process, especially learning resources that are able to explore the ideas of students into an innovative and critical so that they can produce and solve theirown problems,through problem-based LKPD learning. This method and type of research is a development study with a 4-Dmodelby Thiagarajan and Semmel. The findings in this study are the use of problem-based learning-based LKPD and the response of students who were found to be positive or good
\end{abstract}

Keyword; StudentWorksheet, Problem Based Learning, Learning Outcomes

\section{INTRODUCTION}

The quality of human resources is a big and long-term problem because it concerns the nation's education. When discussing education, it is not separated from the school as a container that brings together elements of education. The school as a formal institute is a vehicle in the institution of acceptance of the purpose of education. Through school, students train themselves a variety of things. In formal education, practice shows a positive transformation so that in the final phase will be able to new skills, skills and insights. But in an effort to achieve adequate results, a learning system is needed. In the teaching and learning system, teachers have a position as director as well as actor and are the dominant aspect in determining the success of the teaching and learning system in the classroom. 
According to Suyanto (1999:6),economic learning is not only so that students have a better interpretation of history and social sciences. However, what really means is training students to think rationally and also assume carefully. Furthermore, the purpose of learning is to improve the skills of students in analyzing economic situations and problems in a logical way. Because economics can also be used to solve problems of individual and public economic problems, economics needs to be taught and studied by teachers and students.

Based on the results of interviews conducted by researchers with one of the economics teachers at Medan Student Park Private Vocational School showed that the achievement of student learning outcomes was still not in line with expected. Where the minimum completion criteria for Business Economics subjects are 75 . Details can be observed in table 1. 1:

Table 1.1

Percentage of Completion of Students Class X OTKP Mata Pelajaran Business Economics Year of Learning 2020/2021

\begin{tabular}{|c|c|c|c|c|c|c|}
\hline Class & $\begin{array}{c}\text { Sum } \\
\text { Student }\end{array}$ & KKM & $\begin{array}{c}\text { Students with } \\
\text { SKKM grades }\end{array}$ & Percentage & $\begin{array}{c}\text { Students with } \\
\geq K K M \text { grades }\end{array}$ & Percentage \\
\hline X OTKP-1 & 29 & 75 & 17 & $58,62 \%$ & 12 & $41,37 \%$ \\
\hline X OTKP-2 & 26 & 75 & 16 & $61,53 \%$ & 10 & $38,46 \%$ \\
\hline
\end{tabular}

\section{Source: DKN Business Economics SMK Taman Siswa Medan}

From the table above it can be seen that the average of the results of the final repeat grade of the semester for class X OTKP-1 who obtained a score greater than KKM which is $41 \%$ or as many as 12 students, and who obtained a score smaller than KKM which is $59 \%$ or as many as 17 students, and for class X OTKP-2 who obtained more than KKM which is $38 \%$ or as many as 10 students, and who get a score smaller than KKM which is $62 \%$ or as many as 16 students. Sourced from the data obtained, jelas that thepercentage of learning of students is still low in categories and has not achieved success in learning in accordance with what is set. This proves that the learning outcomes of students must be improved.

Low learning outcomes are thought to be influenced by several factors such as variations in the learning model used. The learning model still uses conventional methods (monotony) as a result of which teachers are not yet experts in directing the attention of students to follow the learning, so that many students are still less observing. According to Wahyuningsih (2014:95),the process of learning to teach 
with a teacher centered nature is very easy for teachers but for students it is a saturated and not easy matter, consequently affecting the thinking skills of students.

The last factor that attracts the attention of researchers is that teachers have not been able to compile and develop teaching materials, especially LKPD. According to Katriani (2014: 1), LKPD is a collection of sheets containing student activities that allow learners to carry out real activities with the objects and problems studied. LKPD acts as a guideline for learning learners and also makes it easier for learners and teachers to carry out teaching and learning activities so as to increase the participation of students or students' activities in learning and change the learning situation from teacher centered to student centered".

LKPD provided from the school is not the result of the development of the school teacher. However, LKPD is obtained from publishers that have been provided and the internet, so teachers have not developed LKPD to guide their students to increase student engagement and student activity in learning. Teachers still rely on package books from the government even though one of the weaknesses of the government package book according to the Ministry of Education (in Rosliana, 2019:13) "When observed from the structure, namely the absence of learning instructions, supporting information and the stage of question-solving activities so that in their use, the use of package books only allows one-way communication that has an impact on the lack of opportunities of learners. To improve the mindset including creativity of thinking and less support learners in creating their own knowledge so that it has an impact on the skills of understanding concepts that are less well honed".

The curriculum in Indonesia is currently curriculum 2013 in particular (Regulation of the Minister of Education and Culture of the Republic of Indonesia Number 70 of 2013, 2013) on the Basic Framework and Structure of vocational curriculum / MAK which states that the 2013 Curriculum was developed with the improvement of mindset, among others: educationthat focuses on teachers so focuses on students, as well as passive learning so active learning. Therefore, as a teacher can develop the learning process, especially learning resources that are able to explore the ideas of students into an innovative and critical so that they can produce and solve their own case problems.

One of the efforts to achieve learning goals in accordance with the 2013 curriculum is the need for teaching materials that support learning systems that focus on students and are active in learning. One of the teaching materials is the Student Worksheet or often referred to as LKPD. The existence of LKPD, students have a handle on learning resources so that students can learn independently to produce students' thinking skills. But in reality in the field, there are still many conventional-based LKPDs that are monotonous and saturated for students end up less motivated to assume more innovative and critical. Moreover, there are still 
many LKPD encounters that are not in accordance with basic competencies and curriculum indicators in 2013 because the worksheets submitted in the form of disposable worksheets, just buy and without the efforts of teachers to design, prepare and assemble themselves in increasing their creativity to design in making LKPD more creative and innovative in suppressing students to be more active and critical in producing their knowledge.

With these problems, overcoming the weaknesses of student worksheets in business economics learning, teacher creativity is needed in improving student worksheets. In the development of student worksheets in accordance with the 2013 curriculum, conformity of existing problems is needed by utilizing the basis of the combined learning model. Andarwati and Hernawati (2013:166) stated that "the application of LKPD requires a learning model that can create new knowledge". By utilizing the basis of the learning model, the preparation of LKPD can support students so as not to have difficulty in mastering learning and actively participating in the teaching and learning process. Currently, there are many learning models that can be used by a teacher in improving the learning outcomes of students, one option isto use the problem-based learning model that can give the widest space to students to be able to think and participate actively in the learning process.

According to Aryanti (2020:6) that:

Problem Based Learning is a learning model that utilizes real-world problems as a context for students to learn critical thinking and problem-solving skills, and to gain the main knowledge and concepts of the subject matter. Problem Based Learning emphasizes on students to be independent learning and actively involved in learning.

From the expert statement above it can be concluded that learning with the Problem Based Learning model begins with a problem (can be raised by teachers or students), after which students deepen their knowledge about what they already know and what they need to know to solve the problem. Students can sort out problems that are considered interesting to solve so that they are encouraged to play an active role in learning.

Sourced from the results of interviews with teachers in the field of Business Economics studies at the Medan Student Park Vocational School that they have never utilized student worksheets (LKPD)based on problem based learning and the way to learn to teach is still conventionally based. The learning model must be able to change the learning style of students from students who learn passively so active in constructing theories. The right learning model can create more useful, fun, and suitable learning for students. Therefore, teachers must be able to be creative and innovative in teaching and be able to raise the concern of students to be active and motivated to learn, and must be balanced with the teacher's expertise in 
understanding the model. Related to this researchers choose a problem based learning model.

This is related to the research put forward by Benny Satria Wahyudi, Slamet Hariyadi, Sulifah Aprilya Hariani (2014) entitled "Development of Teaching Materials Based on Problem Based Learning Model on Environmental Pollution Subjects to Improve The Learning Outcomes of Students of Class X Grujugan Bondowoso State High School", that the hypothesis that reads the development of teaching materials based on problem based learning models on the subject of environmental pollution is able to improve the learning outcomes of Students of State High School Grujugan Bondowoso", that the hypothesis that reads the development of teaching materials based on problem based learning models on the subject of environmental pollution is able to improve the learning outcomes of Students of State High School Grujugan Bondowoso", that the hypothesis that reads the development of teaching materials based on problem based learning models on the subject of environmental pollution is able to improve the learning outcomes of Students of Class X Grujugan Bondowoso State High School", that the hypothesis that reads the development of teaching materials based on problem based learning models on the subject of environmental pollution is able to improve the learning outcomes of Students of State High School Grujugan Bondowoso", that the hypothesis that reads the development of teaching materials based on problem based learning models on the subject of environmental pollution is Increase the learning outcomes of students of grade X Grujugan Bondowoso State High School can be accepted.

Sourced from theabove ka sus, researchers attempted to study the problem with the title "Developmentof Student Worksheet (LKPD) Based on Problem Based Learning to Improve Learning Outcomes in Mata Pelajaran Business Economics Students Class X OTKP Private Vocational School Medan T.P 2020/2021".

\section{METHOD}

This type of research is development research (Research and Development). Development research aims to develop, improve and test the effectiveness of a product. This development research refers to the 4-Dmodelby Thiagarajan and Semmel (1974). This model has four stages:define,design,development(develop)and disseminate. However, in this study only carried out until the stage of development (without the disseminate stage). Products developed in research are teaching materials in the form of problem-based learning LKPD that has the potential impact to improve student learning outcomes.

This research will be conducted at the Medan Student Park Private Vocational School which is located at Jalan Sabaruddin No. 8 Medan. Wactutu research conducted in semester genap Year of Learning 2020/2021. This sampling is done 
by means of total sampling. Thus this study can be referred to as population research i.e. class $\mathrm{X}-\mathrm{OTKP}^{1}$ and $\mathrm{X}-\mathrm{OTKP}{ }^{2}$. Where the 1 st experimental class uses LKPD based problem based learning model and experiment class 2 uses LKPD based conventional learning model.

The assessment instruments are questionnaires, observations and tests of learning results. The required questionnaires are as follows: (1) Assessment questionnaires or responses from LKPDmaterialexperts; (2) Assessment or response questionnaires from LKPDdesignexperts; (3) Assessment or response questionnaires from business economics teachers; (4) Angket assessment or student response to LKPD. The content of the questionnaire is in the form of statements related to the condition or circumstances of LKPD based on Problem Based Learning in learning.

Data analysis techniques are used to formulate research results. The results of this data analysis are the answer to the question of the existing problem. The collected data is analyzed descriptively quantitatively and then the results of the analysis are described qualitatively. The data to be collected is data related to LKPD product development assessment data based on Problem Based Learning on business economics learning for vocational class $\mathrm{X}$ semester 2 through a team of experts, teachers and students. On the questionnaire sheet uses the Likert scale with 5 alternative answers available with different weights. The results of the questionnaire sheet will be adjusted to the benchmarks used to interpret the percentage of expert validation questionnaire results as well as the responses of teachers and students. The test used is an objective test of multiple choices with 5 answer choices (a,b, c,d,e) about consumer and producer behavior materials. Before hypothesis testing is first done test data analysis requirements in this case calculated data normality test and data homogeneity test. To test the hypothesis of learning outcomes, the test used is the $t$ test.

\section{RESULTS AND DISCUSSION}

The research was conducted at The Medan Student Park Private Vocational School 2020/2021 involving two classes with different treatment in both classes. Class X-OTKP ${ }^{1}$ is used as an experimental class I which is given LKPD based on Problem Based Learning model and $\mathrm{X}-\mathrm{OTKP}^{2}$ is used as an experiment class II which is given LKPD based on conventional learning model.

Before conducting research into the field, researchers validated the LKPD developed to 3 validators, namely 2 expert lecturers and teachers in the field of study. The validation process is carried out 1 stage because the results of validation of $1 \mathrm{LKPD}$ are said to be worth trialling without revision with an average percentage of $87 \%$. 
LKPD trials are carried out with 2 stages, the first is a small group trial stage and the second stage of trials in the field. In the small group trial stage as well as field trials, the student response was very positive, with a very decent category with a percentage greater than $80 \%$. After this stage is completed, the next stage to find out the feasibility of LKPD developed towards improving learning outcomes.

Before learning begins, pre-tests are held to both classes aimed at looking at students' initial abilities in consumer and producer behavior materials. Researchers pretested the I and II trials using as many as 20 valid multiple choice questions.

After being given different treatment, namely the first experimental class that was given a collaborative treatment of problem basedlearning model, and the second experimental class that was taught with conventional learning models, it was given back post tests to see improvements in learning outcomes. With the post test, the average score was obtained in the first experimental class of 81.03 with 27 students from a sample of 29 students declared to pass KKM. As for the second experimental class, the average score was 74.81 with 22 students from a sample of 26 students declared to pass KKM.

After the calculation using the Liliefors technique, the pre-test normality test for the experimental class I obtained Lcount $=0.106$. From the list of liliefors tests with real levels $\alpha=0.05$ with $n=29$, the table $L=0.161$ is obtained. This indicates the $\mathrm{L}_{\text {count }}<$ Ltable $(0.106<0.161)$ meaning normal distributed data. Post-testtest class experiment I obtained $\mathrm{L}_{\text {count }}=0.132$. From the list of liliefors tests with real levels $\alpha=0.05$ with $n=29$, the table $\mathrm{L}=0.161$ is obtained. This shows $\mathrm{L}_{\text {calculated }}<\mathrm{L}_{\text {table }} 0.132$ $<0.161$ meaning normal distributed data.

While the pre-test normality test for experimental class II obtained Lcount $=$ 0.069 . From the list of liliefors tests with real levels $\alpha=0.05$ with $n=26$ then obtained Ltable $=0.173$. This shows Lcalculates the $<$ Ltable $(0.069<0.173)$ meaning normal distributed data. Post-test test class experiment II obtained $\mathrm{L}_{\text {count }}=0.106$. From the list of liliefors tests with real levels $\alpha=0.05$ with $n=26$ then obtained Ltable $=0.173$. This shows Lcalculates the $<$ Ltable $(0.106<0.173)$ meaning normal distributed data.

From the homogeneity test calculation using the interpolation calculation obtained $\mathrm{F}_{\text {table }}=1.88$, Fthe $_{\text {count }}$ for the pre test data is 1.19 and Fthe $\mathrm{C}_{\text {count }}$ for post test data is 1.18. By comparing the price obtained $F_{\text {calculate }}<F_{\text {table }}$ which is $1.19<1.88$ for pre test data and $\mathrm{F}_{\text {calculates }}<\mathrm{F}_{\text {table }}$ which is $1.18<1.88$ for post test data. It can then be concluded that the variance of both sample groups for pre test and post test has the same variance or homogeneous.

Furthermore, the t-test results were conducted, where the test results were found to have an increase in the learning outcomes of students who used LKPD problem based learning on consumer and manufacturer behavior materials compared to the learning results of students who used conventional LKPD (student 
handbook) with significance values of 0.05 and $t_{\text {calculated }}>t_{\text {tables }}(2.71>1,664)$. While based on the calculation of improvement in student learning outcomes from the average post-test grade in the first experimental class (LKPD problem based learning)obtained81.03 and the experiment class II (Conventional LKPD) obtained 74.81. Thus, $H_{a}: \mu \bar{X}_{1}>\mu \bar{X}_{2}=81.03>74.81$, so it can be concluded that the results of learning business economics taught using LKPD based problem based learning model are higher than the results of business economics learning taught using LKPD. based on conventional learning model in students of class X OTKP SMK Private Taman Siswa Medan 2020/2021.

The results of this study are supported by the results of previous research conducted by Lestari with his research entitled "Procedural Adopting 4D Model from Thiagarajan A Study of Biotechnology MSMEs Using PBL Models for Students. The results of this study showed that draft validation from experts was worth $92.1 \%$ with good criteria. Validation of the draft by practitioners of $94.5 \%$ with excellent criteria. The trial of students amounted to $88.2 \%$ with good criteria. The results of the implementation of MFI in the field based on cognitive assessments in 34 students with a pre-test score of 51,912 and post test 61,618 . Statistical tests show a significant difference between pre-test and post test scores. Thus it can be concluded that the hypothesis that reads the application of the PBL model MFI can effectively improve learning outcomes in Biotechnology courses is acceptable.

From the overall analysis of data from the results of the study, it can be concluded that the research I conducted that the results I can also experience improvements in student learning outcomes, the use of problem-based learningbased LKPD is feasible and the student response is found to be positive or good.

\section{CONCLUSION}

Based on the results of research and discussion, it can be concluded as follows:

1. The development of problem-based learning LKPD that has been developed in Consumer and Producer Behavior materials for students of class X OTKP SMK Swasta Taman Siswa Medan, the overall results of validation with an average percentage of $87 \%$ declared worthy of use in the teaching and learning process.

2. The results of the student response assessment at the small group trial stage and field trials, tested positive i.e. with a very decent category with a percentage greater than $80 \%$.

3. The results of the test- $t$ found an increase in the learning outcomes of students who used LKPD problem based learning on consumer and producer behavior materials compared to the learning results of students who used conventional LKPD (student handbook) with significance values of 0.05 and $t_{\text {calculated }}>$ tables $(2.71>1,664)$, aswell as results $\mu \bar{X}_{1}>\mu \bar{X}_{2}=81.03>74.81$. This shows the 
learning outcomes of business economics taught using LKPD-based problem based learning models are significantly higher than business economics learning outcomes taught using LKPD-based conventional learning models.

Based on the results of the study and conclusions, the researchers provide the following suggestions:

1. For teachers who want to implement the development of problem-based learning LKPD should be adjusted to the analysis and needs of students during learning by following the steps of the problem based learning model so that students can engage more enthusiastically and can cooperate in the team.

2. LKPD developed must be made with a more creative or more interesting design so that all students are interested in working on LKPD.

3. For further researchers who want to conduct similar research to first conduct the feasibility test of LKPD before being used by teachers of the field of study and students.

\section{REFERENCES}

Amir, M. T. (2010). Inovasi Pendidikan Melalui Problem Based Learning. Jakarta: Kencana Prenada Media Group.

Andarwati, D dan Hernawati, K. (2013). Pengembangan Lembar Kegiatan Siswa (LKS) Berbasis Pendekatan Penemuan Terbimbing Berbantuan Geogebra Untuk Membelajarkan Topik Trigonometri pada Siswa Kelas X SMA. Prosiding FMIPA UNY, pp. 978-979 ISBN : 978-979-16353-9-4. https://eprints.uny.ac.id/10745/1/P\%20-\%2022.pdf. (diakses pada 12 Maret 2021 pukul 10.32).

Arikunto, Suharsimi. (2014). Evaluasi Program Pendidikan. Jakarta: Bumi Aksara.

Arikunto, Suharsimi. (2018). Prosedur Penelitian Suatu Pendekatan Praktek. Jakarta: Rineka Cipta.

Aryanti. (2020). Inovasi Pembelajaran Matematika di SD. Sleman: Deepublish Publisher.

Djamarah, Syaiful dan Aswan Zain. (2016). Strategi Belajar Mengajar. Jakarta: Rineka Cipta.

Elfina, Sisra dan Sylvia. (2020). Pengembangan Lembar Kerja Peserta Didik (LKPD) Berbasis Problem Based Learning (PBL) dalam Meningkatkan Kemampuan Berpikir Kritis Siswa Pada Mata Pelajaran Sosiologi di SMA Negeri 1 Payakumbuh. Jurnal Kajian Pendidikan dan Pembelajaran. Volume 2 Nomor 1 September (2020) 27-34, ISSN: 2686-3413 (Print) 2715-1735 
(Online), http://sikola.ppj.unp.ac.id/index.php/sikola/article/view L56. (diakses pada 18 Maret 2021 pukul 11.05).

Hamruni. (2012). Strategi Pembelajaran. Yogyakarta: Insan Madani.

Istarani dan Intan Pulungan. (2015). Ensiklopedi Pendidikan. Medan: Media Persada.

Jasperina dan Suryelita. (2019). The Development of Problem Based Learning Student Worksheet on Alkanale and Alkanone Topics for 3rd Grade of Senior High School. Edukimia Journal. Volume 1 Nomor 3 Oktober 112-117, e-ISSN: 2502-6399, http://edukimia.ppj.unp.ac.id/ojs/index.php/edukimia/. (diakses pada 18 Maret 2021 pukul 11.15).

Karwono. (2018). Belajar dan Pembelajaran. Depok: Rajawali Pers.

Kaharuddin, A. (2018). Effect of Problem Based Learning Model on Mathematical Learning Outcomes of 6 th Grade Students of Elementary School Accredited B in Kendari City. International Journal of Trends in Mathematics Education Research, (2), pp. 43-46. doi:10.33122/ijtmer.v1i2.14. https://core.ac.uk/download/pdf/23006 1677.pdf. (diakses pada 13 Maret 2021 pukul 18.40).

Katriani, Laila.(2014). Pengembangan Lembar Kerja Peserta Didik (LKPD). Makalah disampaikan dalam PPM "Pelatihan Pembuatan Perencanaan" bagi Guru SMP Se-Kecamatan Danurejan, Kota Yogyakarta. Jurusan Universitas Negeri Yogyakarta (UNY), Yogyakarta, 24 Oktober. http://staff.uny.ac.id/sites/default/files/pengabdian/laila-katrianissi-msi/pengembangan-lembar-kerja-peserta-didik-lkpd-ppm-dipafakultas-20141.pdf. (diakses pada 18 Maret 2021 pukul 12.24).

Kaymakci, S. (2006). History Teachers' Views About Worksheets. Turkey: Karadeniz Technical University.

Kompri. (2017). Belajar: Faktor-Faktor yang Mempengaruhinya. Yogyakarta: Media Akademi.

Latief, Dede dan Epon. (2014). Pengaruh Pembelajaran Kontekstual terhadap Hasil Belajar. Jurnal Pendidikan Geografi, Volume 14 Nomor 1 (2014) 1127, https:// ejournal.upi.edu/index.php/gea/article/view/3358.

(diakses pada 02 Desember 2020 pukul 12.10).

Lestari. (2018). Prosedural Mengadopsi Model 4D dari Thiagarajan Suatu Studi Pengembangan LKM Bioteknologi Menggunakan Model PBL Bagi Mahasiswa. Jurnal Ilmiah Teknologi FST Undana, Volume 12 Nomor 2 September (2018) 56- 
65, https://ejurnal.undana.ac.id/jurnal_teknologi/article/view/1170 . (diakses pada 12 Maret 2021 pukul 14.03).

Lukman, Kembaren dan Mariani. (2019). Pengembangan Lembar Kerja Siswa Inovatif Berbasis Problem Based Learning Dalam Pembelajaran Konsep Materi Kimia Reaksi Reduksi dan Oksidasi pada Siswa SMA. Prosiding Seminar Nasional Peningkatan Mutu Pendidikan, Volume 1 Nomor 1 Desember (2019) 457-463, http://publikasi.fkipunsam.org/index.php/semnas2019/article/view/116/110. (diakses pada 02 Desember 2020 pukul 12.37).

Ngalimun. (2017). Strategi Pembelajaran : Dilengkapi dengan 65 Model Pembelajaran. Yogyakarta: Penerbit Parama Ilmu.

Nuraini, Johari dan Revis. (2017). Pengembangan Lembar Kerja Siswa Berbasis Problem Based Learning Pada Pembelajaran Biologi untuk Sekolah Menengah Atas. Jurnal Edu Sains, Volume 6 Nomor 1 Januari (2017) 1118, https://online-journal.unja.ac.id/edusains/article/view/5267. (diakses pada 03 Desember 2020 pukul 10.31).

Peraturan Menteri Pendidikan dan Kebudayaan Republik Indonesia Nomor 70 Tahun 2013. (2013). Peraturan Menteri Pendidikan dan Kebudayaan Republik Indonesia Nomor 70 Tahun 2013 tentang Kerangka Dasar dan Struktur Kurikulum Sekolah Menengah Kejuruan/Madrasah Aliyah Kejuruan. Jakarta: Depdiknas.

Polya, G. (1973). How to Solve It: A New Aspect of Mathematical Method (Second Edition). New Jerey: Princeton University Press. https://notendur.hi.is/hei2/teaching/Polya_HowToSolveIt.pdf.

Prastowo, A. (2013). Panduan Kreatif Membuat Bahan Ajar Inovatif. Yogyakarta: Diva Press.

Purwanto. (2012). Prinsip-Prinsip dan Teknik Evaluasi Pengajaran. Bandung: Rosda Karya.

Qohar. (2017). Pengembangan Perangkat Pembelajaran Model Problem Based Learning untuk Meningkatkan Keterampilan Berfikir Tingkat Tinggi. Tesis. Jember: Program Studi Magister Pendidikan Matematika Universitas Jember. https://repository.unej.ac.id/handle/123456789/81027. (diakses pada 13 Maret 2021 pukul 09.26).

Rosliana, Ina. (2019). Pengembangan LKPD Matematika dengan Model Learning Cycle 7E Berbantuan Mind Mapping. Jurnal Pengembangan Pembelajaran Matematika, Volume 1 Nomor 1 Februari (2019) 1022, http:/ / ejournal.uin- 
suka.ac.id/saintek/jpm/article/view/1357/1223. (diakses pada 01 Februari 2021 pukul 10.29).

Rusman. (2014). Model-model Pembelajaran : Mengembangkan Profesionalisme Guru. Jakarta: Rajagrafindo Persada.

Sadirman. (2018). Interaksi dan Motivasi Belajar Mengajar. Depok: Rajagrafindo Persada.

Sari, Banowati dan Purwanti. (2018). The Effect of Problem-Based Learning Model Increase The Creative Thinking Skill and Students Activities on Elementary School. Journal of Primary Education, Volume 7 Nomor 1 April (2018) 57-63 e-ISSN: 2502-4515 p-ISSN: 22526404, https://journal.unnes.ac.id/sju/index.php/jpe/article/view/2 1861. (diakses pada 03 Desember 2020 pukul 11.05).

Sitepu, B.P. (2012). Penulisan Buku Teks Pelajaran. Bandung: PT Remaja Rosdakarya.

Sudjana. (2009). Metoda Statistika. Bandung: PT Tarsito.

Sugiyono. (2016). Metode Penelitian Kuantitatif, Kualitatif dan RED. Bandung: Alfabeta.

Suyanto. (1999). Pokok-Pokok Pembelajaran Pendidikan Ekonomi di SLTP. Jakarta: Departemen Pendidikan Nasional.

Tim Prodi Pendidikan Sosiologi FIS UNY. (2019). Instrumen Penilaian Keterampilan Mata Pelajaran Sosiologi SMA: LKPD (Lembar Kerja Peserta Didik). Yogyakarta: UNY Press.

Trianto. (2014). Mendesain Model Pembelajaran Inovatif-Progresif. Jakarta: Kencana Prenada Media Group.

Usman, Uzer. (2017). Menjadi Guru Profesional. Bandung: Remaja Rosdakarya. Usmeldi. (2015). Pengembangan Lembar Kerja Siswa dalam Pembelajaran Fisika Berbasis riset di SMAN 1 Padang. Prosiding Seminar Nasional Fisika (EJournal ), Volume IV Oktober 2015, pp. 185-190 p-ISSN: 2339-0654 eISSN: 2476-9398, http://journal.unj.ac.id/unj/index.php/prosidingsnf/article/downlo ad/5007/3693/. (diakses pada 12 Maret 2021 pukul 11.36).

Wahyudi, Benny Satria, dkk. (2014). Pengembangan Bahan Ajar Berbasis Model Problem Based Learning pada Pokok Bahasan Pencemaran Lingkungan untuk Meningkatkan Hasil Belajar Siswa Kelas X SMA Negeri Grujugan Bondowoso. Jurnal Pancaran, Vol. 3 No. 3, Agustus 2014. https://jurnal.unej.ac.id/index.php/pancaran/article/view/765. (diakses pada 17 Maret 2021 pukul 18.09). 
Wahyuningsih, dkk. (2014). Pengembangan LKS Berbasis Inkuiri Terbimbing Pada Materi Pokok Hidrolis Garam Untuk SMA/MA. Jurnal Paedagogia, Vol. 17 No. 1, 2014, 0126-4109 ISSN (Print), 2549-6670 ISSN (Online), https://jurnal.uns.ac.id/paedagogia/article/view/36061. (diakses pada 12 Maret 2021 pukul 12.11) 